УДК 910.3(470.325)

РЕКРЕАЦИОННЫЙ КАРКАС ГОРОДА БЕЛГОРОДА

Королева И.С.

ФГАОУ ВО «Белгородский государственный национальный исследовательский университет», Белгород, e-mail: koroleva_i@bsu.edu.ru

\begin{abstract}
В современных условиях прогрессирующей урбанизации рекреационная среда является необходимым компонентом пространственно-планировочной структуры города, которую необходимо учитывать при разработке новых стратегий развития территорий. Рекреационная среда города взаимосвязана и взаимообусловлена с рекреационной деятельностью в существующем рекреационном каркасе, а его качество напрямую зависит от качества существующего рекреационного каркаса и разнообразия рекреационной деятельности в нем происходящей. Цель исследования - оценка рекреационного потенциала природных территорий рекреационного каркаса города. Объект исследования - рекреационный каркас города Белгорода. Для достижения поставленной цели использовались методы сравнительного анализа, статистический и картографический методы, структурно-функциональный подход. Автором была дана формулировка термину рекреационный каркас, оценка рекреационного потенциала природных территорий рекреационного каркаса с учетом функциональной модели оценки для планировочного района и объекта. В работе были рассмотрены элементы туристско-рекреационной системы г. Белгорода, его функциональные зоны, проанализирована обеспеченность населения зелеными насаждениями, выявлены зоны транспортной доступности природных территорий и определена рекреационная нагрузка на них. Рекреационный каркас г. Белгород является формирующимся, в нем присутствуют буферные элементы, обеспечивающие поддержание экологической устойчивости, но в то же время создаются новые площадные и линейные объекты. Формирование последних в рекреационном каркасе города обусловлено экоревитализацией, позволяющей с помощью консервации и декорирования создать «непрерывные» рекреационные коридоры, проложенные вдоль рек города. Рекреационный потенциал природных территорий рекреационного каркаса оценивается как благоприятный и относительно благоприятный. Проведенная рекреационная оценка природных территорий выявила проблемы и перспективы развития.
\end{abstract}

Ключевые слова: рекреационный каркас, рекреационный потенциал, озеленение, транспортная доступность

\title{
RECREATIONAL FRAMING OF BELGOROD CITY
}

\section{Koroleva I.S.}

Federal State Autonomous Educational Institution of Higher Education Belgorod State National Research University,Belgorod,e-mail: koroleva_i@bsu.edu.ru

\begin{abstract}
In modern conditions of progressive urbanization, the recreational environment is an essential component of the spatial planning structure of the city, which must be taken into account when developing new strategies for the development of territories. The recreational environment of the city is interconnected and interdependent with recreational activities in the existing recreational framework, and its quality directly depends on the quality of the existing recreational framework and the variety of recreational activities occurring in it. The aim of the study is to assess the recreational potential of natural areas of the recreational framework of the city. The object of research is the recreational framework of the city of Belgorod. To achieve this goal, the methods of comparative analysis, statistical and cartographic methods, structural and functional approach were used. The author formulated the term recreational frame, assessment of the recreational potential of natural areas of recreational frame taking into account the functional evaluation model for the planning area and the object. Elements of tourist and recreational system of Belgorod, its functional zones were considered, provision of the population with green plantings is analyzed, zones of transport accessibility of natural territories are revealed and recreational loading on them is defined. The recreational framework of Belgorod is emerging, it contains buffer elements that ensure the maintenance of environmental sustainability, but at the same time, new areal and linear objects are created. The formation of the latter in the recreational framework of the city is due to eco-revitalization, which allows using conservation and decoration to create «continuous» recreational corridors laid along the rivers of the city. The recreational potential of the natural areas of the recreational framework is assessed as favorable and relatively favorable. The conducted recreational assessment of natural territories revealed problems and prospects of development.
\end{abstract}

Keywords: recreational framework, recreational potential, landscaping, transport accessibility

В современных условиях прогрессирующей урбанизации рекреационная среда является необходимым компонентом пространственно-планировочной структуры города, которую необходимо учитывать при разработке новых стратегий развития территорий. В современном мире наиболее эффективным и комплексным научно-практическим подходом современного градостроитель- ства к планированию, развитию и трансформации городов являются концепции, обусловленные созданием гибкой социально-ориентированной структуры, трансформирующейся под изменения в окружающем пространстве и позволяющей сохранить экологическую устойчивость городских экосистем. С последней тесно переплетены ландшафтный урбанизм, биоурбанистика, 
экологический урбанизм и другие, направленные на преобразование городских территорий и формирование каркаса, обеспечивающего экологическую устойчивость и улучшающего качество окружающей среды, в которой проживает человек [1]. В научной литературе встречается множество вариаций каркаса - экологический [2, 3], эколого-рекреационный, природно-рекреационный, рекреационный $[4,5]$. Это обусловлено тем, что рекреационный каркас города выполняет рекреационное обслуживание, архитектурно-планировочное регулирование, эстетическое, санитарно-гигиеническое, природоохранное, климаторегулирующее и биологическое обеспечение [4], в то же время озелененные пространства улучшают ветровой, шумовой, радиационный режимы, ионизацию и фитонизацию воздуха, создают микроклиматический комфорт для жизнедеятельности городского населения [6], способствуют профилактике заболеваний средствами ландшафтной рекреации. Анализ литературы свидетельствует о возрастании научного интереса к реализации функций рекреации через создание рекреационнооптимальной структуры урбанизированных пространств.

Цель исследования: оценка рекреационного потенциала природных территорий рекреационного каркаса города. Объект исследования - рекреационный каркас города г. Белгород.

\section{Материалы и методы исследования}

Для проведения исследования была выбрана территория г. Белгорода и его пригород. Эмперической базой исследования послужили статистические данные Белгородстата, по состоянию природных и социально-экономических ресурсов города и различные исследования в данных областях, и фондовые материалы управления архитектуры и градостроительства г. Белгорода. В исследовании применялись методы сравнительного анализа, статистический и картографический методы, структурно-функциональный подход.

\section{Результаты исследования и их обсуждение}

Рекреационный каркас территории города - устойчивая рекреационная среда, перспективная и используемая городским населением для восстановления его здоровья. Рекреационный каркас территории связан с существующей туристско-рекреационной системой и формируется и развивается вместе с ней. На территории Бел- городской агломерации выделяют такие композиционные, функциональные и планировочные элементы туристско-рекреационной системы, как ареалы, ядра, оси, локусы. Река Северский Донец выступает как «ось» туристско-рекреационной системы, имеющей вид «ожерелья» - по ее берегам располагаются «локусы» и «ядра». Другой «осью» туристско-рекреационной системы выступает река Везелка. Побережье р. Везелка и Северский Донец представляют собой крупный линейный элемент рекреационной системы - набережную протяженностью 15,5 км. Еще одной осью туристскорекреационной системы выступают дороги областного и регионального значения. При рассмотрении туристско-рекреационной системы г. Белгорода озелененные территории, достопримечательности и объекты рекреационной инфраструктуры выступают в качестве локусов городского пространства реализующих разнообразные рекреационные функции (рис. 1). Основная их часть расположена в границах Центрального и Южного планировочных районов. Их роль и ценность высока для жителей города.

Площадь зеленых насаждений общего пользования постоянно увеличивается, так в 1980-х гг. был высажен массив «Сосновка». В настоящее время в черте г. Белгорода и его пригорода находятся зеленые насаждения общего пользования, представленные 12 лесопарками, 7 парками, 5 бульварами, 36 скверами, 3 аллеями, 10 рекреационными зонами и набережной [7]. Вопросы озеленения города и создания зеленого каркаса по-прежнему актуальны, поскольку ощущается недостаток озелененных общественных пространств [8, 9].

Оценка рекреационного потенциала природных территорий рекреационного каркаса города следует проводить с учетом комплекса показателей и четким указанием объекта оценки - планировочного района (квартала) и природного объекта. Рекреационный потенциал последнего рассматривают как совокупность индикаторов: статус, площадь, озеленение, емкость, санитарно-гигиеническое состояние, доступность, благоустройство, безопасность, ценность рекреационного объекта, разнообразие выполняемых функций, коэффициент рекреационного потенциала планировочного района. Оценка городских рекреационных территорий по перечисленным показателям будет оцениваться как суммарное значение, помноженное на коэффициенты разнообразие выполняемых функций, рекреационный потенциал планировочного района. 


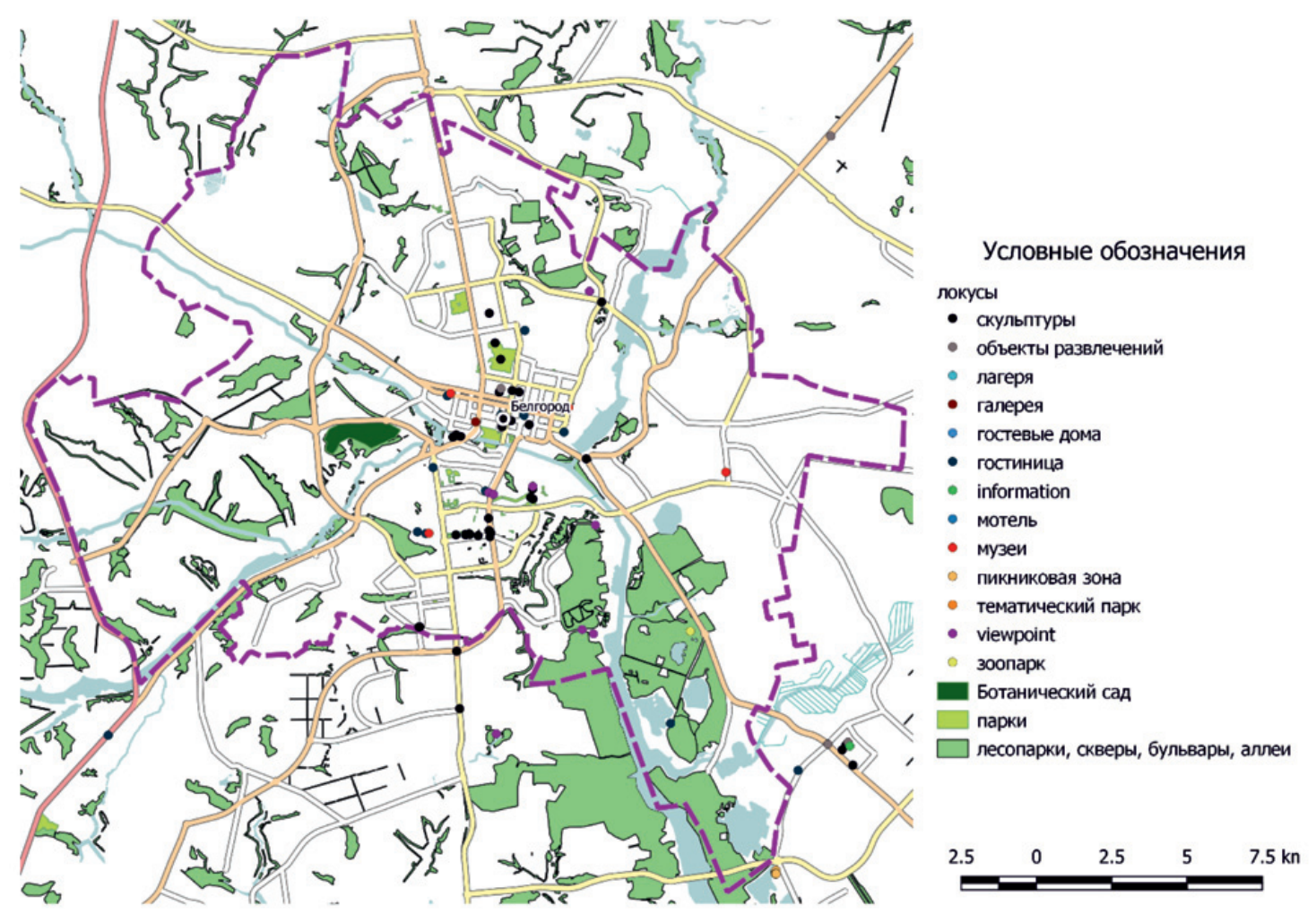

Рис. 1. Локусы туристско-рекреаџионной системы г. Белгорода

Насаждения общего пользования

Таблица 1

\begin{tabular}{|l|c|c|c|c|c|c|}
\hline \multicolumn{1}{|c|}{ Район } & $\begin{array}{c}\text { Парки, } \\
\text { га }\end{array}$ & $\begin{array}{c}\text { Лесопарки, } \\
\text { га }\end{array}$ & $\begin{array}{c}\text { Скверы, бульвары, } \\
\text { аллеи, га }\end{array}$ & $\begin{array}{c}\text { Сады, } \\
\text { га }\end{array}$ & $\begin{array}{c}\text { Общая } \\
\text { площадь, га }\end{array}$ & $\begin{array}{c}\text { Обеспеченность } \\
\text { на 1 чел./га }\end{array}$ \\
\hline Центральный & 45,1 & 154 & 38,96 & - & 238,06 & 0,00335 \\
\hline Южный & 43 & 360,6 & 19,71 & 71 & 494,31 & 0,0033 \\
\hline Западный & - & 50 & 1 & - & 51 & 0,0008 \\
\hline Восточный & 25,2 & 996 & 1,19 & - & 1022,39 & 0,0144 \\
\hline Итого & 113,3 & 1560,6 & 60,86 & 71 & 1805,76 & 0,0046 \\
\hline
\end{tabular}

Согласно требованиям нормативной документации, суммарная площадь озелененных территорий общего пользования,

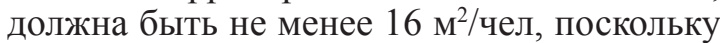
г. Белгород относится к категории крупных городов. Таким образом, в городе должно быть не менее 0,62 тыс. га зеленых насаждений общего пользования [9]. Согласно «Программе комплексного развития социальной инфраструктуры городского округа «Город Белгород» на 2017-2025 годы» планируемая площадь зеленых насаждений в 2025 г. составит 0,64 тыс. га [10].

По данным федеральной службы государственной статистики в г. Бел- городе на 1 января 2019 г. проживает 392,4 тыс. чел., обеспеченность зелеными насаждениями при площади 1805,76 га составила $46 \mathrm{~m}^{2} /$ чел (табл. 1).

Зеленые насаждения общего пользования представлены во всех планировочных районах, однако они достаточно разрознены. Зеленые территории, располагающиеся в пределах планировочного района, используются для ежедневной рекреационной деятельности, а те, что находятся в соседних планировочных районах - для еженедельной. В восточном планировочном районе располагается $56,6 \%$ зеленых насаждений общего пользования (табл. 1). Обеспечен- 
ность зелеными насаждениями составляет 0,0144 чел/га. В его границах располагается формирующийся «Мультипарк «Белгородский».

Удельный вес озелененных пространств г. Белгорода составляет $31,5 \%$, что на $8,5 \%$ ниже принятой нормы. Отмечается диспропорция в структуре функциональных зон г. Белгорода. Соотношение между производственной, селитебной и рекреационной территориями составляет соответственно $11,2 \%$ - 18,9\% - 11,4\% (1:1,7:1) вместо $1: 2: 3$ [7]. Согласно Генеральному плану развития городского округа «Город Белгород» до 2025 г. доля рекреационных территорий достигнет $14,7 \%$, а соотношение между функциональными зонами города будет составлять 1:2,3:1,2. Таким образом, и в 2025 г. останется актуальной проблема увеличения доли рекреационных зон в 3 раза. Увеличение доли рекреационных зон планируют за счет формирования рекреационных зон в пригородной лесопарковой зоне, рекреационного обустройства промышленных районов города.

Особое внимание при оценке зеленых насаждений следует уделить рекреационным коридорам - скверам и аллеям. Наиболее развитая сеть рекреационных коридоров характерна для Центрального планировочного района - самой старой части города (табл. 1). Для этого района характерно коттеджная застройка, 1-2-этажные здания в историческом центре и 5-этажные здания севернее исторической части города. Озеленение микрорайона составляет 70\%. На втором месте по площади рекреационного коридора находится Южный район. Для него характерно многоэтажное жилищное строительство, начатое в 1970-е гг. и продолжающееся до настоящего времени. В Центральном планировочном районе самая большая площадь занята парками. В зависимости от вида городского рекреационного объекта и численности населения проводилось ранжирование рекреационных территорий по обеспеченности озелененной территорией, позволяющей восстановить психологические и физические силы человека. Самыми крупными парками являются Пикник-парк и зоопарк, расположенные в Южном и Восточном районах соответственно (рис. 2).

В дальнейшем проводилась оценка озеленения территории парков (озеленение $90 \%$ ), скверов (не менее $75 \%$ ), лесопарков (более 90\%). Расчет процента озеленения территории производится в геоинформационной системе на основе данных космоснимков в таблице атрибутивов с помощью инструмента CalculateField. Так в соответствии с нормативами, в парке культуры и отдыха им. В.И. Ленина площадь озеленения должна составлять не менее 154610 га. В настоящее время это значение ниже.

В зависимости от площади и типа насаждений зеленые территории имеют ориентировочный уровень предельной рекреационной нагрузки. Рекреационная емкость лесопарков и парков представлена в табл. 2 . Так предельная рекреационная нагрузка на зеленые территории Центрального планировочного района не должна превышать 21220 человек. В соответствии с нормами рекреационных нагрузок для лесной и лесостепной зоны ООПТ «Городской лес» среднегодовая рекреационная емкость территории лесопарка для экскурсий будет составлять 265 чел/га, для планового туризма 88 чел/га, для самодеятельного туризма 40 чел/га, для массового повседневного отдыха 66 чел/га.

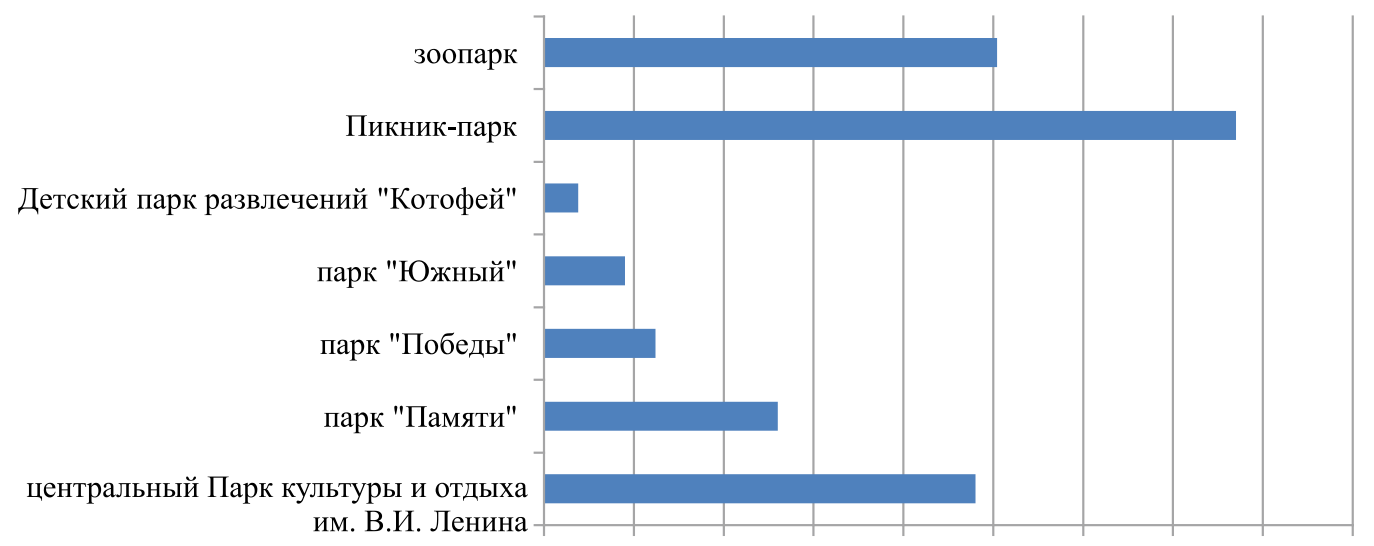

Рис. 2. Площуадь парков г. Белгорода 
Таблица 2

Рекреационная емкость лесопарков, парков Центрального планировочного района

\begin{tabular}{|l|c|c|}
\hline \multicolumn{1}{|c|}{ Название } & Площадь, га & Рекреационная емкость, чел \\
\hline ООПТ «Оскочное» & 56,0 & 2800 \\
\hline ООПТ «Уткина Яруга» & 31,4 & 1570 \\
\hline ООПТ «Кондраковское» & 17,1 & 855 \\
\hline ООПТ «Городской лес» & 44,2 & 2210 \\
\hline ООПТ «Гринево» & 5,3 & 265 \\
\hline Центральный Парк культуры и отдыха им. Ленина & 24 & 7200 \\
\hline Парк «Памяти» & 13 & 3900 \\
\hline Парк «Победы» & 6,2 & 1860 \\
\hline Детский парк развлечений «Котофей» & 1,9 & 570 \\
\hline Итого & 199,1 & 21220 \\
\hline
\end{tabular}

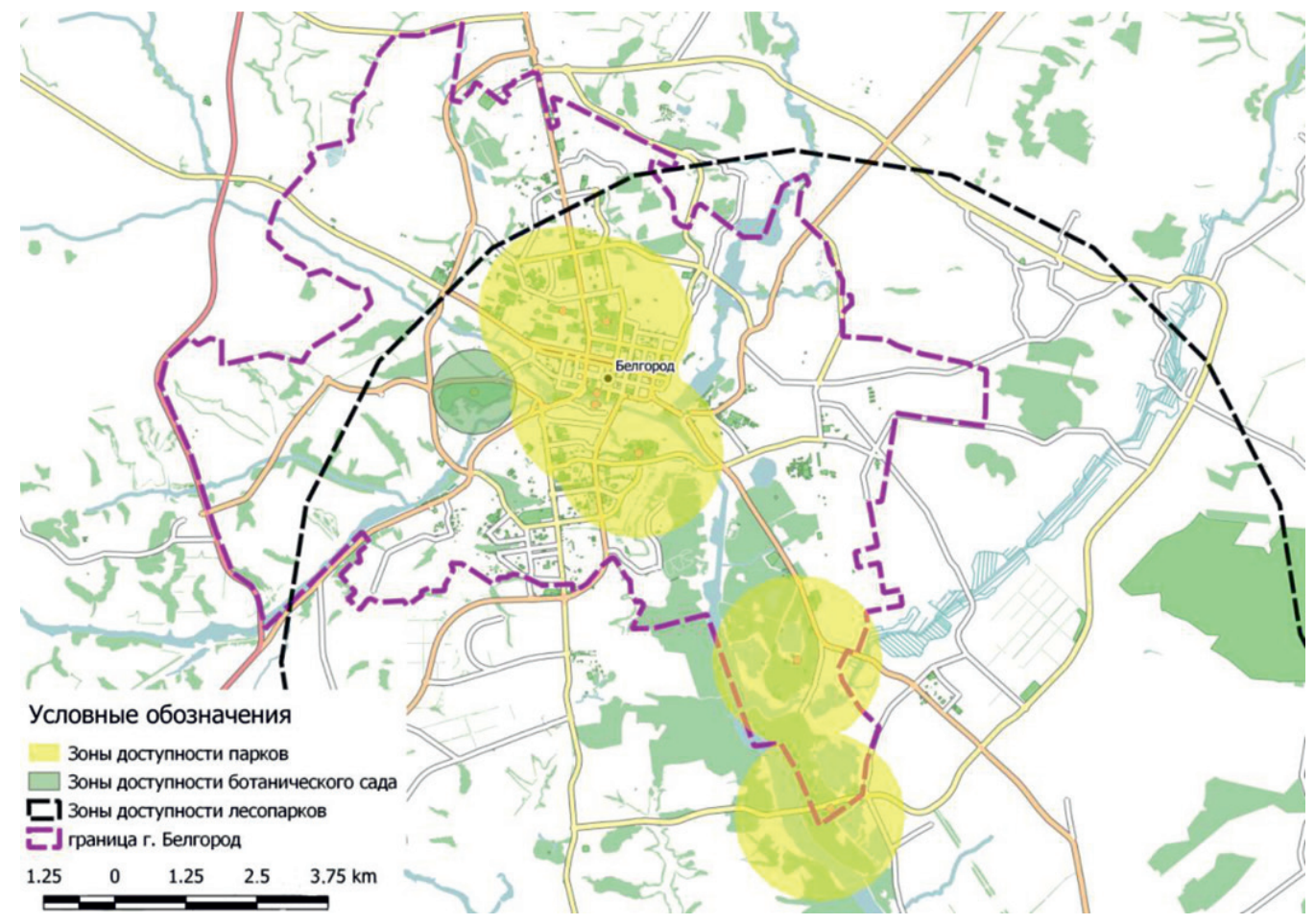

Рис. 3. Радиус обслуживания населения г. Белгорода

На следующем этапе оценки, в геоинформационной системе от границ парка (не более 1200 м), лесопарка (20 км), сквера (400 м), сада (600 м) строились буферные зоны в соответствии с заданными расстояниями. Соответственно с этими нормативами данная граница считалась конечной точкой при оценке благоприятности рекреационной территории. Если жилые кварталы, для которых проектировался данный рекреационный объект, попадали в буферную зону превышающую заданные параметры, то она оценивалась как небла- гоприятная. Согласно полученным данным парки города находятся в пределах транспортной доступности для жителей своего планировочного района (Центрального, Южного и Восточного планировочных районов) г. Белгорода, лесопарки - ООПТ «Сосновка», «Массив» в зоне транспортной доступности для Восточного и Центрального планировочного районов и частично для Южного планировочного района (рис. 3). Если Пикник парк и Зоопарк относить к категории лесопарков, а не парков, то в радиус обслуживания населения попадают Юж- 
ный, Восточный и частично Центральный планировочные районы.

Рекреационный потенциал г. Белгорода также зависит от такого аттрактивного свойства, как состояние рекреационных объектов. По этому показателю территория оценивалась как благоприятная, относительно благоприятная и неблагоприятная. Благоприятное состояние характерно для лесопарков ООПТ «Оскочное», «Каменный лог», «Половинное», «Массив», «Сосновка», «Лесничество» и всех парков, за исключением парка Памяти и Центрального парка культуры и отдыха им. В.И. Ленина, которые нуждаются в реконструкции и оцениваются как относительно благоприятные.

При оценке безопасности рекреационного объекта учитывали следующие составляющие: оценка для здоровья рекреантов, опасность противоправных действий в отношении рекреантов, опасность со стороны технических средств. При оценке безопасности рекреационного объекта для здоровья рекреантов в первую очередь учитывался породный состав насаждений. Так территория Пикник парка благоприятна не для всех категорий отдыхающих, поскольку хвойные насаждения негативным образом влияют на состояние здоровья людей больных сердечно-сосудистыми заболеваниями. Нахождение в посадках аллей тополей негативным образом сказывается на здоровье людей страдающих аллергией, поскольку вызывает астматические приступы. Также необходимо учитывать состояние древостоя. По данному показателю все зеленые насаждения отнесены к категории благоприятных.

Городские рекреационные территории г. Белгорода имеют местный, региональный и федеральный статус. При оценке рекреационных объектов коэффициент на 1,5 будет увеличиваться рекреационная ценность Белгородского государственного музея-диорама «Курская битва. Белгородское направление», Белгородского государственного музея народной культуры, селище 1 (Дальние Пески) и другие. Коэффициент 1,3 будет применяться для Преображенского, Иосафовского соборов, Крестовоздвиженской церкови, жилого дома купца Мачурина, усадьбы графини А.В. Ластовской, церкви Михаила Архистратига и других. При этом такой показатель, как ценность рекреационного объекта, будет низкой для усадьбы графини А.В. Ластовской, поскольку элементы величия здания сохранились лишь во внутренней отделке. В настоящее вре- мя данный объект не способен привлечь для отдыха жителей других микрорайонов, городов и стран. Парки, находящиеся в Центральном и Южном планировочном районах, также не способны привлечь для отдыха жителей других микраройонов, городов и стран, за исключением парка «Победы». В нем была проведена реконструкция и в летний период он привлекает гостей из области. Остальные рекреационные территории нуждаются в реконструкции.

В то же время формирующийся «Мультипарк «Белгородский», находящийся в Восточном планировочном районе, привлекает жителей других микрорайонов и гостей из области, хотя находится в неблагоприятной зоне транспортной доступности.

Для выявления коэффициента рекреационной ценности планировочного района было проведено ранжирование территории по плотности объектов развлечения и питания. При зонировании территории был взят квадрат площадью 25 га. Результаты зонирования показали наличие двух ядер сосредоточения объектов питания, проживания, развлечения и культурно-исторических объектов - это Центральный и Южный районы. В настоящее время по берегам реки Северский Донец формируется рекреационное ядро межрегионального значения - формирующийся «Мультипарк «Белгородский», который уже включает в себя зоопарк, динопарк, парк-отель «Европа», ресторан «Лес и Лис» и другие локусы.

\section{Выводы}

Таким образом, в пределах города продолжает формироваться рекреационный каркас. Рекреационный потенциал природных территорий рекреационного каркаса оценивается как благоприятный и относительно благоприятный. Элементы рекреационного каркаса - ООПТ, выступают в нем в качестве буферных территорий. В структуре рекреационного каркаса г. Белгорода выделяются крупные и малые площадные и линейные структуры. Формирование последних в рекреационном каркасе города обусловлено экоревитализацией, позволяющей с помощью консервации и декорирования создать «непрерывные» рекреационные коридоры, проложенные вдоль рек города. В то же время проведенная оценка позволила выявить необходимость расширения сети рекреационных коридоров в Южном планировочном районе и зоны в нем не обеспеченные природными территориями. 


\section{Исследование выполнено при финансо- вой поддержке РФФИ и Правительства Белгородской области в рамках научного проекта № 18-45-310008.}

\section{Список литературы / References}

1. Петрина О.А., Стадолин М.Е. Комфортная городская среда: тенденции и проблемы организации // Вестник университета. 2018. № 6. С. 34-38. DOI: 10.26425/1816-4277-2018-6-34-38.

Petrina O.A., Stadolin M.E. Comfortable urban environment: trends and problems of organization // Vestnik universiteta. 2018. № 6. P. 34-38 (in Russian).

2. Ливенцева А.В., Лисова О.С. Рекомендации по формированию природно-экологического каркаса крупного города (на примере г. Воронежа) // Архитектурные исследования. 2016. № 1. С. 65-74.

Liventseva A.V., Lisova O.S. Recommendations on the formation of natural and ecological framework of a large city (in example. Voronezh) // Arkhitekturnyye issledovaniya. 2016. № 1. P. 65-74 (in Russian).

3. Молостов А.Н., Мулендеева А.В. Экологический каркас Чебоксарского городского округа // Эколого-геоморфологические исследования в урбанизированных и техногенных ландшафтах (Арчиковские чтения - 2015). Сборник материалов Всероссийской летней молодежной школы-конференции (Чебоксары, 23-28 августа 2015 г.). Чебоксары: ЦНС «Интерактив плюс», 2015. С. 243-249.

Molostov A.N., Mulendeeva A.V. Ecological framework of Cheboksary city district // Ekologo-geomorfologicheskiye issledovaniya $\mathrm{v}$ urbanizirovannykh i tekhnogennykh landshaf-takh (Archikovskiye chteniya - 2015). Sbornik materialov Vserossiyskoy letney molodezhnoy shkoly-konferentsii (Cheboksary, 23-28 avgusta 2015 g.). Cheboksary: TSNS «Interaktiv plyus», 2015. P. 243-249 (in Russian).

4. Исмагилова C.X., Залётова Е.А. Формирование ландшафтно-рекреационного и транспортного каркасов городского округа г. Казань // Известия КГАСУ. 2016. № 3. C. $110-117$.

Ismagilova S.H., Zaletova E.A. Formation of landscaperecreational and transport frameworks of the urban district of Kazan // Izvestiya KGASU. 2016. № 3. P. 110-117 (in Russian)

5. Казаков Н.А., Еремеева С.С., Караганова Н.Г., Михайлова Е.В. Природно-рекреационный каркас городского округа и долины малых рек (на примере города Чебоксары) // Успехи современного естествознания. 2018. № 7 . C. $136-141$
Kazakov N.A., Eremeeva S.S., Karaganova N.G., Mikhailova E.V. Natural and recreational framework of the urban district and the valley of small rivers (on the example of the city of Cheboksary) // Advances in current natural sciences. 2018. № 7. P. 136-141 (in Russian).

6. Василенко Н.А. Системные принципы формирования ландшафтно-рекреационной среды крупного города: автореф. дис. ... канд. арх. наук. Москва, 2009. 23 с.

Vasilenko N.A. System principles of formation of landscape and recreational environment of a large city: avtoref. dis. ... kand. arkh. nauk. Moscow, 2009. 23 p. (in Russian).

7. Королева И.С., Королев А.С. Процесс урбанизации береговых пространств современного города (на примере Белгородской городской агломерации) // Успехи современного естествознания. 2018. № 4. C. 127-132. DOI: 10.17513/use.36736.

Korolyova I.S., Korolev A.S. The process of urbanization of coastal spaces of the modern city (on the example of the Belgorod urban agglomeration) // Advances in current natural sciences. 2018. № 4. P. 127-132 (in Russian).

8. Программа комплексного развития социальной инфраструктуры городского округа «Город Белгород» на 20172025 годы. [Электронный ресурс]. URL: www.beladm.ru/ media/publication backbone media/2017/7/26/okonchatelnaya-programma-s24b9f65bfd8127ff613f10e 7363 e $388 d$ docx (дата обращения: 19.10.2019).

The program of complex development of social infrastructure of the city district «City of Belgorod» for 20172025. [Electronic resource]. URL: www.beladm.ru/media/ publication backbone media/2017/7/26/ okonchatelnayaprogramma-s24b9f65bfd8127ff613f10e7363e388d.docx (date of access: 19.10.2019) (in Russian).

9. Полякова Т.А. Состояние и оценка функциональнопланировочной структуры крупного города (на примере г. Белгорода): автореф. дис. ... канд. геогр. наук. 2011. 23 с.

Polyakova T.A. State and assessment of the functional and planning structure of a large city (on the example of Belgorod): avtoref. dis. ... kand. geogr. nauk. 2011. 23 p. (in Russian).

10. Об утверждении генерального плана городского округа «Город Белгород» Белгородской области. Распоряжение Департамента строительства и транспорта Белгородской области от 14 марта 2018 года № 185. [Электронный ресурс]. URL: http://docs.cntd.ru/document/550205838 (дата обращения: 17.10.2019).

About the approval of the master plan of the city district «The city of Belgorod» of the Belgorod region. The order Of Department of construction and transport of the Belgorod region of March 14, 2018 № 185. [Electronic resource]. URL: http:// docs.cntd.ru/document/550205838 (date of access: 17.10.2019) (in Russian). 